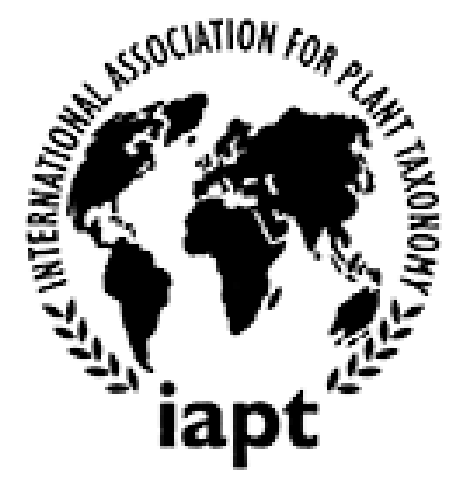

Greguss's Morphogenera of Homoxylous Fossil Woods: A Taxonomic and Nomenclatural Review Author(s): Marc Philippe, Gea Zijlstra, Maria Barbacka and Greguss

Source: Taxon, Vol. 48, No. 4 (Nov., 1999), pp. 667-676

Published by: International Association for Plant Taxonomy (IAPT)

Stable URL: http://www.jstor.org/stable/1223638

Accessed: 12/02/2015 11:30

Your use of the JSTOR archive indicates your acceptance of the Terms \& Conditions of Use, available at http://www.jstor.org/page/info/about/policies/terms.jsp

JSTOR is a not-for-profit service that helps scholars, researchers, and students discover, use, and build upon a wide range of content in a trusted digital archive. We use information technology and tools to increase productivity and facilitate new forms of scholarship. For more information about JSTOR, please contact support@ jstor.org. 


\title{
Greguss's morphogenera of homoxylous fossil woods: a taxonomic and nomen- clatural review
}

\author{
Marc Philippe ${ }^{1}$, Gea Zijlstra ${ }^{2} \&$ Maria Barbacka ${ }^{3}$
}

\begin{abstract}
Summary
Philippe, M., Zijlstra, G. \& Barbacka, M.: Greguss's morphogenera of homoxylous fossil woods: a taxonomic and nomenclatural review. - Taxon 48: 667-676. 1999. - ISSN 00400262.

Greguss proposed several generic names for homoxylous woods in the 1950s and 1960s. Several are, however, not validly published or fall into synonymy. The present review is based on the re-examination of the original material and protologues. The new combination Agathoxylon parenchymatosum is proposed as a consequence of such re-examination.
\end{abstract}

\section{Introduction}

After Gothan and Eckhold, Greguss is perhaps the most prolific author of names of morphogenera for fossil woods. Mainly a neoxylologist, he wrote world-famous books (Greguss, 1955a, 1959, 1967) about both soft- and hardwoods. Neoxylology was always his main subject of research (Gulyás, 1984) but in the 1940s, encouraged by Elemér Vadász of the Hungarian Geological Survey, he began to study fossil woods as well.

Despite the unique value of Greguss's work, his publications are not free of nomenclatural errors and mistaken interpretations. Being unacquainted with the traps of fossilisation, it seems that Greguss was fooled several times by preservational structures in his fossil woods.

Greguss's nomenclatural treatment was avowedly etymological. In one of his papers (Greguss, 1955b, Consp.: 100), he explained his approach as follows: "the writer is applying the rule according to which if a Tertiary wood agrees perfectly in its structure with that of a recent genus, ... it is to be identified by the recent generic name with the suffix "xylon'". In such cases he seldom used the designation "nov. gen.", even when he was the first author to publish a certain name (e.g., Laricioxylon). Because many of the corresponding genera comprised only one species, described as new, their names have to be accepted as validly published under Art. 42 of the Code. Only when a specimen of fossil wood could not be associated with a non-fossil genus did Greguss choose an entirely new name, and then he always used the designation "nov. gen." (e.g., Pseudagathoxylon). Greguss's "etymological" approach makes his work difficult to interpret, and moreover caused him regularly to violate the rules (see, e.g., Agathoxylon). Furthermore, his approach is often difficult to interpret nomenclaturally as, probably because of supererogatory caution, his phraseology regularly includes indications of doubt (see, e.g., Pteridospermaexylon). The repository of his type material is only rarely indicated. Because in many cases

\footnotetext{
${ }^{1}$ Laboratoire de Paléobotanique, 401A, 43 boulevard du 11 Nov 1918, F-69622 Villeurbanne cedex, France (email: philippe@cismsun.univ-lyon1.fr).

${ }^{2}$ Herbarium, Heidelberglaan 2, NL-3584 CS Utrecht, Netherlands (email: zijlstra@accu.uu.nl).

${ }^{3}$ Botanical Department, Hungarian Museum of Natural History, Budapest Pf. 222, H-1476 Hungary (email: barbacka@bot.nhmus.hu).
} 
there is no indication that more than one specimen was studied and described, the corresponding new species names must nevertheless be accepted as validly published under the Code (Art. 37.3).

Although commonly used and quoted, Greguss's generic names have never been reviewed. This paper attempts a reappraisal of the generic names he proposed for homoxylous woods. We found that most of them are either not validly published or fall into synonymy.

\section{Material and methods}

At his death, Greguss left a huge collection of slides and a rich library, but he did not succeed in arousing great interest in wood anatomy among the students he supervised. While expecting that the Hungarian National Museum in Budapest or a new museum especially founded for that purpose woutd eventually receive his collections, Greguss used to keep his original material at home, where the facilities for its methodical arrangement were inadequate (L. Hably, pers. com.). Shortly after his death, the slide collection was moved in great haste to the József Attila University, and apparently some material was lost in the process (M. Kedves, pers. comm.). Also, some of the fossil wood material he studied was returned to diverse institutions during his lifetime, where its safeguard was sometimes neglected. Therefore, some holotypes may have been dispersed, or have lost any indication of their type status.

Through careful examination, we were able to trace some of the original material (Philippe \& Barbacka, 1997). The screening of slides for details that were illustrated allowed the secure identification of some holotypes. Some slide sets proved to be composite. Collections were studied from the following institutions: the Hungarian Natural History Museum (HNHM), the József Attila University in Szeged (JAS), and the Hungarian Geological Survey collection in Rakóczitelep (GSR).

All generic names proposed by Greguss or attributed to him were reviewed, whether or not they were validly published, and irrespective of expressions of doubt. Apart from names explicitly stated to represent a "nov. gen.", we consider as new any generic name for which Greguss provided some explanation of why he chose it, without indicating that he knew of its prior existence. Our format follows the Index nominum genericorum (Farr \& al., 1979, 1986), a work that only lists validly published names and thus omits several of those that are considered here. Some invalid names are listed, however, by Andrews (1970), Blazer (1975), or Watt (1982). On the other hand, Blazer missed several valid names that were published with a "nov. sp." (but without "nov. gen." in the heading).

Names that are not validly published are placed between quotation marks. The abbreviation $I N G$ refers to the Index nominum genericorum (Farr \& al., 1979, 1986), Code stands for the International code of botanical nomenclature (Greuter \& al., 1994). The term "morphogenus" is used in preference to "form-genus" following a corresponding decision by the St Louis Congress, in 1999.

\section{Results}

Agathoxylon Greguss (1952: 160, 169 [non Hartig 1848]). - Type: A. hungaricum (Andr.) Greguss (Simplicioxylon hungaricum Andr.).

This generic name is listed by ING but is absent from Andrews (1970), although this work cites Greguss's (1952) paper. 
Greguss restudied material previously described as Simplicioxylon hungaricum by Andreánszky (1949). He disagreed with the latter's statement that the secondary wood is of an extremely simple structure (hence the name: Simplicioxylon) and, having compared the fossil with Araucaria and Agathis, concluded that it can be considered as identical with present-day species of Agathis, so that the name Agathoxylon must be applied.

We found no proof that Greguss was aware in 1952 of Hartig's (1848) work, as he might well have been since he spoke German fluently and had frequent contact with researchers of the Natural History Museum in Berlin (H. Süss, pers. comm.). On the other hand, a map in Greguss (1967: 34, map 1) of the non-fossil and fossil distribution of Agathis, besides Cretaceous sites on several continents, shows Mesozoic sites in Hungary only, and none is indicated for the Triassic in Germany (from where the type of Hartig's name originates). To conclude, there is no indication that Greguss was adding a species to Hartig's genus, and Agathoxylon should be treated as newly proposed by Greguss.

Agathoxylon Greguss is not only illegitimate as a later homonym (Code, Art. 53). As A. hungaricum includes all syntypes of Simplicioxylon hungaricum Andr. (see Philippe, 1995; Philippe \& Barbacka, 1997), the type of Simplicioxylon Andr., Agathoxylon is also a nomenclaturally superfluous substitute for the latter name.

Baieroxylon Greguss (1961: 142). - Type: B. implexum (Gerda Zimm.) Greguss (Dadoxylon implexum Gerda Zimm.).

Several authors dismiss Baieroxylon, either as xylologically not well defined (Süss, 1988) or as of doubtful ginkgoalean affinity (Scott \& al., 1962). The description of the single original species, Dadoxylon implexum, was based on two samples (syntypes: Code, Art. 9.4). However, as Zimmermann bases her specific diagnosis on the sample from Grab, emphasising that its preservation is very good (Zimmermann, 1953: 81), and as she has some reservation as to the specific attribution of the Marbächle sample (op. cit.: 84 ), we here designate the Grab sample (op. cit.: text-fig. 5 \& t. 28, f. 1-6) as lectotype, with G. Zimmermann's approval. The thin-sections of both syntypes are kept at the Institut für spezielle Botanik und Mykologie, University of Tübingen (F. Oberwinkler, pers. comm.). Greguss's material of this species is in JAS.

\section{“Callitroxylon” (Greguss, 1967: 55).}

This generic name appears in a heading as "?Callitroxylon sp.". It is not associated with any species name, and thus is not validly published (Code, Art. 37.1 \& 10.1). The identity of the material is stated with doubt: "some kind of Callitris, though with no absolute certainty". Greguss's slides are in JAS. The wood preservation is too poor for determination.

\section{“Chamaeparioxylon” (Greguss, 1960: 13).}

This name is explicitly proposed for a "nov. gen.". It is based on a "sample L" (Greguss, 1960: text-fig. 4; t. 4, f. 13-16). No species name, however, is proposed for this sample "L". Chamaeparioxylon is thus not validly published (Code, Art. $37.1 \& 10.1$ ). Greguss had some doubt as to the fossil's identity, stating that it resembles Chamaecyparis more than it does Sequoia. It is peculiar that in this par- 
ticular case the designation "nov. gen." is used. Greguss (1967) renamed "sample L" as "Glyptostroboxylon sp. $\mathrm{n}^{\circ}$ 3", without mentioning his earlier paper. We did not manage to trace the original material.

“Cryptomerioxylon” (Greguss, 1967: 66).

This generic name appears in a heading as "?Cryptomerioxylon sp.", is not associated with any species name, and thus is not validly published (Code, Art. 37.1 \& 10.1). The sample's identity, again, is given with some doubt: "So we qualify the fossil with some reservation as Cryptomerioxylon." The material is in JAS, but is poorly preserved.

\section{“Dacrydioxylon” (Greguss, 1967: 34).}

This name is explicitly proposed for a "nov. gen.", and two species are described. However, Greguss did not designate the type of the generic name, which by consequence is not validly published (Code, Art. 37.1).

In fact, the two species are given a different treatment, as Greguss clearly associated the new generic name with Dacrydioxylon estherae ("n. gen. et n. sp.") rather than D. tasnadi-kubacskanum ("n. sp.").

\section{Laricioxylon Greguss (1967: 97). - Type: L. nogradense Greguss.}

Perhaps due to a misprint, Watt (1982) registered this genus as "Laricioxylon Greguss 1969", but as a matter of fact correctly cited the page and illustration for this generic name, as published in Greguss (1967).

The case of Laricioxylon (with its single named species designated as "n. sp.") illustrates that Greguss in 1967 still followed the same policy as in 1955: "Since the fossil examined is a Larix by all certainty, we propose to name it as Laricioxylon." Even though Greguss evidently was not aware of having created a new generic name, Laricioxylon is validly published under Art. 42 of the Code, with the descriptive matter validating $L$. nogradense serving as descriptio generico-specifica.

$I N G$ did not take up this generic name because in the same work Greguss mentioned a second, different fossil as "?Laricioxylon sp.", so that the genus was considered not to be monotypic, and Art. 42 inapplicable. By decision of the Sydney Congress in 1981, the Code (Art. 42.2) now defines a "monotypic genus" as one for which a single binomial is validly published, even though the author may indicate that other (unnamed) species belong to the genus. The case of Laricioxylon has therefore been reconsidered, and the name will be added to the $I N G$ database.

We did not manage to trace the holotype of Laricioxylon nogradense. According to Greguss it should be in the Hungarian National Museum under No. 6140/1. A thorough search of HNHM only revealed a set of three slides, without name or locality indication, numbered 61.401.1; and a second set of unnumbered slides originating from the holotype locality (Nagradszakall). So far, xylological details of the original illustrations could not been matched on any of these slides, which shows that Greguss's indications of the holotype repository are not always reliable (Philippe \& Barbacka, 1997). 
Libocedroxylon Greguss (1967: 56 [non Hudajberdyev, 1964]). - Type: L. gaussenii ('gausseni') Greguss.

There is nothing in Greguss's treatment that would justify the assumption that he knew that this generic name already existed. In his distribution map (Greguss, 1967: map 6, p. 57) he only indicated the present distribution of Libocedrus, along with its Tertiary locality in Hungary. We thus consider Libocedroxylon Greguss as a new generic name, validly published under Art. 42 of the Code. Penny (1947) had already used the name Libocedroxylon, but did not, however, validly publish it: the characters in his descriptive key are based on non-fossil wood of Libocedrus and related genera, and he had seen no fossil material. Therefore, Art. 34.1(b) of the Code applies: "the name is merely proposed in anticipation of the future acceptance of the group concerned, ..."; in other words, in case fossil wood resembling Libocedrus might be found.

We did not manage to trace the holotype of Libocedroxylon Greguss. It has not therefore been possible, so far, to decide whether this name can be considered as a junior taxonomic synonym of Libocedroxylon Hudajberdyev. As in the case of Laricioxylon, Greguss's name is not in the published ING but will be included in the $I N G$ database.

\section{"Metasequoioxylon" (Greguss, 1967: 69).}

Greguss was quoted by Watt (1982) as the author of Metasequoioxylon. Greguss (1967) described two specimens as "Metasequoioxylon hungaricum" and "?Metasequoioxylon sp.", respectively. In the context of the first name, while making comparisons, Greguss quoted the binomial "Metasequoioxylon germanicum" as "determined by Schönfeld (1955)" [sic]. In fact, no such binomial was used or mentioned anywhere in the cited work: Schönfeld (1955) described only one species, Taxodioxylon metasequoianum. In the same work, Greguss (1967: 77; also in previous works, e.g. Greguss, 1957: 7) correctly referred to Schönfeld's species under the latter name. His treatment of Schönfeld's name here illustrates Greguss's way of nomenclatural thinking: because the wood agrees perfectly with that of a non-fossil genus, the name of that non-fossil genus with the suffix "-xylon" is to be used for it. Apparently he disliked the combination "Metasequoioxylon metasequoianum", so he coined a new epithet, as if there were no priority rules (he probably did not even realise that "Metasequoioxylon germanicum" was anything new). The serious consequence, however, is that the mention of Schönfeld's species implies that Greguss included two named species under "Metasequoioxylon". As no type was indicated nor a separate generic description given, we must conclude that "Metasequoioxylon" was not validly published (Code, Art. $37.1 \& 42$ ).

According to Greguss (1967: 18, footnote), the slides for "Metasequoioxylon hungaricum" are in GSR. However, we did not manage to trace them there.

\section{Palaeocallitroxylon Greguss (1970: 270). - Type: P. limburgense Greguss.}

This generic name is typified by a specimen previously identified as Juniperoxylon silesiacum (W. Prill) Kräusel by Kräusel \& Schönfeld (1924). This specimen, however, belongs to a set of samples which Greguss only partly relates to $P$. limburgense. The "long traces of parenchymatous cells" given as diagnostic by Greguss definitely originate from the mining work of insect larvae (Süss, 1979, 1980). Pa- 
laeocallitroxylon cannot be distinguished from Juniperoxylon Houlbert except on the basis of traumatic structures, and it is thus a junior synonym of the latter.

\section{Platyspiroxylon Greguss (1961: 136). - Type: P. heteroparenchymatosum Greguss.}

Platyspiroxylon has a separate generic diagnosis. Greguss (1967: 47) described a second specimen from Kövágoszõllõs (Hungary) as conspecific with the type, plus $P$. parenchymatosum Greguss as a second species of his new genus. The latter has been moved to Protelicoxylon M. Philippe (1995) on the basis of the original illustration. A first study of the holotype thin-sections (Bx37 in GSR) appeared to confirm this placement (Philippe \& Barbacka, 1997). Subsequent scanning electronic microscopy, however, has clearly shown that the observed spirals are not thickenings but unusually regular furrows due to wood decay, as had already been hypothesised by Jefferson (1987). We therefore formally transfer $P$. parenchymatosum Greguss (1967: 47) to Agathoxylon Hartig, as A. parenchymatosum (Greguss) M. Philippe, Zijlstra \& Barbacka, comb. nov.

Pseudagathoxylon Greguss (1974: 167). - Type: P. eplenyense Greguss.

Although not mentioned in $I N G$, this name was validly published (Philippe, 1993). The diagnosis is written in Hungarian, and an English translation is given in the abstract. After investigation of the original slides in GSR we consider P. eplenyense as a taxonomic synonym of Simplicioxylon hungaricum Andr. (Philippe \& Barbacka, 1997). Investigation of new slide (No. MP928, deposited at the Laboratoire de Paléobotanique of Lyon-1 University, France) prepared from the holotype specimen (a fossil "trunk" stored at the Úrkút Manganese Mine offices in Úrkút, Hungary) fully confirms this opinion.

\section{Pseudotaxodioxylon Greguss (1973: 13). - Type: P. jaehnichenii ('jaehnicheni’) Greguss.}

The diagnosis of this genus is not purely xylological but includes morphological features as well, viz., scars on the outer side of the wood cylinder. Pseudotaxodioxylon is thus not strictly a wood morphogenus. In other words, a piece of isolated secondary xylem cannot be safely placed into this genus unless it shows the morphology of the wood cylinder.

The type material of Pseudotaxodioxylon jaehnichenii is in the Natural History Museum of the Humboldt University in Berlin under the inventory No. 1986/240 (formerly No. 3276; H. Süss, pers. comm.).

A set of slides in GSR, No. Bx14, bears the hand-written label "Pseudotaxodioxylon eplenyense Greguss nov. gen. nov. spec.". The sample originates from the Eplény manganese mine and is said to be Liassic in age. Neither the hand-specimen nor the slides have any xylological affinity with the secondary xylem described by Greguss (1973) in his protologue for Pseudotaxodioxylon, and we have attributed this unpublished material to Simplicioxylon hungaricum (Philippe \& Barbacka, 1997).

\section{Pteridospermaexylon Greguss (1952: 171). - Type: P. theresiae Greguss.}

This name is not included in $I N G$, as it was considered a provisional name and thus not validly published. In the protologue, Greguss indeed wrote: "Vorläufig benenne ich es mit den Namen ...". In our view, this sentence reflects Greguss's 
mannered style of writing rather than real hesitation in proposing the names. The second author now agrees that the wording expresses the kind of taxonomic doubt that is permitted under Art. 34 of the Code, and the name will therefore be included in the $I N G$ database. In the protologue there are several discrepancies between text and plate captions; in particular, the name in the latter is given as "Pteridoxylon".

The specimen upon which the name Pteridospermaexylon is based (Greguss, 1952: t. 13, f. 36, 37, 40) was later reused by Greguss himself (1967: t. 15, f. 3 [enlarged], f. 1 [left-side right] and f. 6 [upside down], respectively) to illustrate his "Araucarioxylon sp. (No. 7)", without any mention of synonymy. The original material has been reinvestigated (Philippe \& Barbacka, 1997) and confidently attributed to Agathoxylon Hartig. Pteridospermaexylon is thus considered a taxonomic synonym of Agathoxylon. The diagnosis of Pteridospermaexylon conflicts with its type in describing the genus as manoxylic whereas the sample is definitely pycnoxylic. As far as we know, no other species has been attributed to this genus.

"Sequoioxylon" (Greguss, 1955b: 275, Consp.: 100 [non Sequoioxylon R. E. Torr., 1923]).

Greguss described a new species, Sequoioxylon turowense, in such a way that one is led to believe that at the same time he was creating a new generic name: "the writer is applying the rule according to which if a Tertiary wood agrees perfectly in its structure with that of a recent genus, ... it is to be identified by the recent generic name with the suffix 'xylon"” (Greguss, 1955b, Consp.: 100).

As Greguss (1952) had already quoted Kräusel (1949), where Torrey's work was mentioned, one might well assume that he was aware of the existence of Sequoioxylon R. E. Torr. However, in a later distribution map (Greguss, 1967: 93, map 11) he does not indicate a Cretaceous locality that would correspond to Torrey's Sequoioxylon. Even though Sequoioxylon Greguss is not designated as "gen. nov.", it is better treated as a new generic name.

Having compared the fossil wood with that of the two non-fossil species of $\mathrm{Se}$ quoia, Greguss concluded that it might belong to one of the known fossil Sequoia species, of which the wood was unknown. "Should it be proved, in the time to come, that the examined lignite cannot be referred to any of the so far identified lignites of Sequoia, the writer proposes to call it Sequoioxylon turowense Greguss n. sp." (Greguss, 1955b, Consp.: 100). We conclude that this binomial is a provisional name, not validly published (Code, Art. 34.1(b)). As there is no generic diagnosis and as Art. 42.2 of the Code does not apply (no validly published binomial exists), the generic name is not validly published either.

\section{Torreyoxylon Greguss (1967: 44). - Type: T. boureaui Greguss.}

The original material of Torreyoxylon boureaui has been investigated (Philippe \& Barbacka, 1997). We consider this name as a taxonomic synonym of Agathoxylon agathiforme (Kedves) M. Philippe \& Barbacka. The generic diagnosis conflicts with the type (e.g., the tracheid radial pitting of the type is typically araucarian and not abietinean at all) and with the original illustration (e.g. Greguss, 1967: t. 32, f. 4; t. 32, f. 5 is touched up). 
Widdringtonioxylon Greguss (1967: 52). - Type: W. raskyae Greguss.

In their revision of the fossil woods related to the Cupressaceae, Vaudois \& Prive (1971) mention Widdringtonoxylon J. S. Penny (1947) and Widdringtonioxylon Greguss (1967). Because Penny's generic name is not in use, and its concept is rejected as too wide by Vaudois \& Privé (1971), we consider Penny's name as unlikely to be confused with Greguss's almost identically spelled name (Code, Art. 53.3).

As for several other new generic names in Greguss (1967), there is nothing in that book to indicate that he intended to create a new name. He quoted Kräusel (1949), who did mention Penny's paper, but nevertheless he was probably unaware of that paper, as in his distribution map (Greguss, 1967: 53, map 5) he failed to indicate any Cretaceous locality that might correspond to Widdringtonoxylon borealis J. S. Penny or any other species that, according to Penny, belongs to Widdringtonoxylon.

$I N G$ does not mention Widdringtonioxylon Greguss, considering that it was not validly published under Art. 42 of the Code (compare Laricioxylon and Libocedroxylon). Greguss's name will now be included in the ING database.

We found some slides in JAS that might belong to the holotype. We cannot, however, be positive about that, and some material may well be in GSR (see Greguss, 1967: 18, footnote).

\section{Discussion}

Among the 17 wood morphogenera proposed by Greguss, only Baieroxylon, Laricioxylon, Platyspiroxylon, and Widdringtonioxylon can be used without problem to designate tracheidoxyls (i.e. isolated secondary xylem pieces: Creber, 1972). For all other validly published genera, the type is transferred to an earlier genus (in some of these cases, the type conflicts with the associated diagnosis), or there are earlier homonyms. Fortunately, Art. 55.1 of the Code makes it clear that species names published under illegitimate generic names can be used as basionyms of legitimate names. Greguss's type specimen repository indications proved again to be unreliable. His taxonomic and nomenclatural approach is sometimes inconsistent.

Greguss's way of naming fossil wood is not unique but is regularly encountered in fossil wood literature, from its early days (c. 1835) up to the 1950s. Several other authors rarely used the designation "nov. gen.". Andreánszky (1952: 20) validly published "Ginkgoxylon bihariense n. sp." for fossil wood that agrees with the wood of non-fossil Ginkgo biloba; this was the first validly publication of that generic name, and moreover Andreánszky stated explicitly that fossil Ginkgo wood was unknown up to that time. Hofmann (1952: 156) validly published "Sonneratioxylon prambachense n. sp." for fossil wood that she believed to belong to Sonneratia, also the first time that this generic name appeared in print. As long as for such a "n. sp." a generic or specific description or diagnosis (and after 1911, an illustration) is given, the generic name is to be accepted as validly published under Art. 42 (and Art. 38) of the Code.

Greguss unquestionably produced a huge and valuable work on fossil wood. His nomenclatural treatment is, however, to be considered with great care, as several of his other indications. A complete revision of his types, mainly those from the Permian and the Tertiary, is badly needed. 


\section{Acknowledgements}

This work formed part of a Franco-Hungarian co-operation programme of the C.N.R.S. and the Hungarian Academy of Sciences. Lilla Hably, Budapest, Mihalik Erzsébet and Kedves Miklós, Szeged, Herbert Süss, Berlin, Franz Oberwinkler, Tübingen, and Gerda Zimmermann, Hofheim, all kindly helped us find our way through their respective collections.

\section{Literature cited}

Andreánszky, G. 1949. Baumstämme aus der unteren Kreidezeit. Földt. Közl. 79: 244-252.

- 1952. Der versteinerte Wald von Mikófalva und einige andere verkieselte Baumstämme aus Ungarn. Ann. Biol. Univ. Hungariae 1: 15-24.

Andrews, H. N. 1970. Index of generic names of fossil plants, 1820-1965. Geol. Surv. Bull. 1300.

Blazer, A. M. 1975. Index of generic names of fossil plants, 1966-1973. Geol. Surv. Bull. 1396.

Creber, J. 1972. Gymnospermous wood from the Kimmeridgian of East Sutherland and from Sandringham Sands of Norfolk. Palaeontology 15: 655-661.

Farr, E. R., Leussink, J. A., \& Stafleu, F. A. (ed.), 1979. Index nominum genericorum (plantarum), 1-3. Regnum Veg. 100-102.

- , Leussink, J. A., \& Zijlstra, G. (ed.), 1986. Index nominum genericorum (plantarum). supplementum 1. Regnum Veg. 113.

Greguss, P. 1952. Magyarországi mezozoi famaradványok. Baumstämme aus den mesozoischen Zeiten. Földt. Közl. 82: 157-180.

- 1955a. Identification of living gymnosperms on the basis of xylotomy. Budapest.

- 1955b. Oznaczenie dolno-miocenskiego pnia drzewa z Toruwa nad Nysa Luzycka. Identification of a Lower Miocene wood from coal-mine at Turów (Poland). Acta Geol. Polon. 5: 273-275; Consp.: 98-100.

- 1957. Ein Lignit aus dem Miozän von Rixhöft (Sequoioxylon germanicum n. sp.). Abh. Deutsch. Akad. Wiss. Berlin, Kl. Chem. 3: 1-10.

- 1959. Holzanatomie der europäischen Laubhölzer und Sträucher. Budapest.

- 1960. Xylotomische Untersuchungen an Braunkohlenfunden von Várpalota. Acta Biol. (Szeged 1955+) 5: 1-16.

- 1961. Permische fossile Hölzer aus Ungarn. Palaeontographica, Abt. B, Paläophytol. 109: 131-146.

- 1967. Fossil gymnosperm woods in Hungary from the Permian to the Pliocene. Budapest.

- 1970. Ein Callitris-ähnliches Holz aus dem Tertiär von Limburg (Niederlande). Senckenberg. Leth. 51:265-275.

- 1973. Die neue systematische Stellung von Cycadinoxylon czeczotti Zalewska, Miozän, Turow VR Polen, und vergleichende Untersuchungen mit Pseudotaxodioxylon jaehnicheni Greguss n. g. n. sp., Miozän, Niederlausitz, DDR. Palaeontographica, Abt. B, Paläophytol. 143: 1-17.

- 1974. Új fenyõ féleség az eplényi jùrakori manganérc bànyàból. A new representative of Coniferae from the Jurassic manganeous ore mine of Eplény. Magyar Állami Földt. Intéz. Évi Jel. 1972: 167-187.

Greuter, W., Barrie, F. R., Burdet, H. M., Chaloner, W. G., Demoulin, V., Hawksworth, D. L., Jørgensen, P. M., Nicolson, D. H., Silva, P. C., Trehane, P. \& McNeill, J. 1994. International Code of botanical nomenclature (Tokyo Code). Regnum Veg. 131.

Gulyás, S. 1984. Necrologue Prof. Dr. Pál Greguss (1889-1984). Acta Biol. (Szeged 1955+) 30: 208-210.

Hartig, T. 1848. Beiträge zur Geschichte der Pflanzen und zur Kenntnis der norddeutschen Braunkohlen-Flora. Bot. Zeitung (Berlin) 6: 122-128, 137-141, 166-172, 185-190.

Hofmann, E. 1952. Pflanzenreste aus dem Phosphoritvorkommen von Prambachkirchen in Oberösterreich. Palaeontographica, Abt. B, Paläophytol. 92: 122-183.

Hudajberdyev, R. 1964. Iskopaemye dreveciny. Turgajskogo tipa. Taškent. 
Jefferson, T. H. 1987. The preservation of conifer wood: examples from the Lower Cretaceous of Antarctica. Palaeontology 30: 233-249.

Kräusel, R. 1949. Die fossilen Koniferen-Hölzer (unter Ausschluss von Araucarioxylon Kraus). II: Kritische Untersuchungen zur Diagnostik lebender und fossiler KoniferenHölzer. Palaeontographica, Abt. B, Paläophytol. 89: 83-203.

- \& Schönfeld, G. 1924. Fossile Hölzer aus der Braunkohle von Süd-Limburg. Abh. Senckenberg. Naturf. Ges. 38: 253-289.

Penny, J. S. 1947. Studies on the conifers of the Magothy flora. Amer. J. Bot. 34: 281-296.

$\rightarrow$ Philippe, M. 1993. Nomenclature générique des trachéidoxyles fossiles mésozoïques à champs araucarioides. Taxon 42: 74-80.

- 1995. Bois fossiles du Jurassique de Franche-Comté (NE-France). Palaeontographica, Abt. B, Paläophytol. 236: 45-103.

- \& Barbacka, M. 1997. A reappraisal of the Jurassic woods from Hungary. Ann. Hist.-Nat. Mus. Natl. Hung. 89: 11-22.

Schönfeld, E. 1955. Metasequoia in der westdeutschen Braunkohle. Senckenberg. Leth. 36: 389-399.

$\rightarrow$ Scott, R. A., Barghoorn, E. S. \& Prakash, U. 1962. Wood of Ginkgo in the Tertiary of western North America. Amer. J. Bot. 49: 1095-1101.

Süss, H. 1979. Durch Protophytobia cupressorum gen. nov., sp. nov. (Agromyzidae, Diptera) verursachte Markflecke in einem Holz von Juniperoxylon aus dem Tertiär von SüdLimburg (Niederlande) und der Nachweis von Markflecken in einer rezenten Callitris-Art. Feddes Repert. 90: 165-172.

- 1980. Fossile Kambium-Minierer der Familie Agromyzidae (Diptera) in tertiären Laubund Nadelholzresten. Z. Geol. Wiss. 8: 1217-1225.

- 1988. Zur Problematik des Nachweises fossiler Gingko-Holzreste. Z. Geol. Wiss. 16: 335336.

Vaudois, N. \& Privé, C. 1971. Révision des bois fossiles de Cupressaceae. Palaeontographica, Abt. B, Paläophytol. 134: 61-86.

Watt, A. D. 1982. Index of generic names of fossil plants, 1974-1978. Geol. Surv. Bull. 1517.

Zimmermann, G. 1953. Anatomische Untersuchungen an Kieselhölzern aus dem Stubensandstein Württembergs. Palaeontographica, Abt. B, Paläophytol. 93: 69-102.

[Ed. Note: Some of the nomenclatural opinions held by the authors are open to controversy. Most would consider Widdringtonioxylon and Widdringtonoxylon, two legitimate names referring to closely related if not identical taxa, to be confusingly similar. Pteridospermaexylon was stated in the protologue to be "provisionally named" by its author, so why would it not be a nomen provisorium, invalid under Art. 34.1(b) of the Code?] 